Prepared for the U.S. Department of Energy under Contract DE-AC05-76RL01830

\title{
Trends in U.S. Venture Capital Investments Related to Energy: 1980 through the Third Quarter of 2010
}

JJ Dooley

November 2010

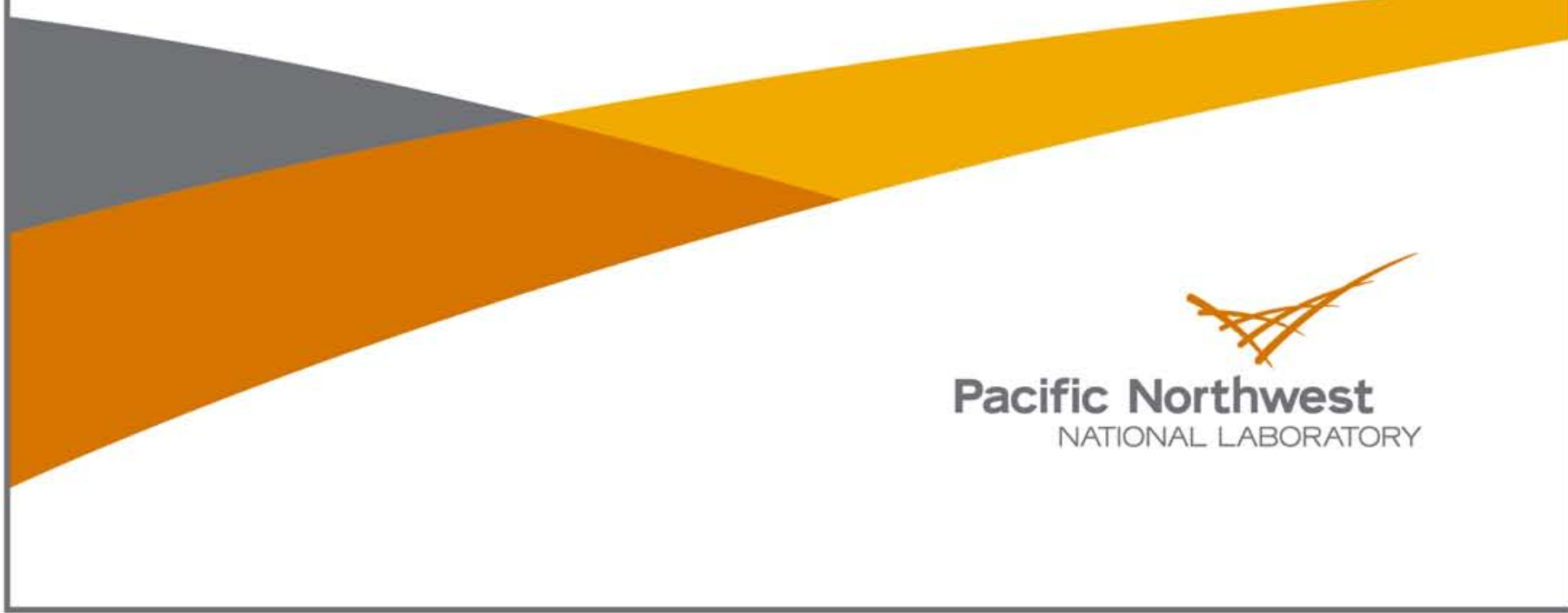




\title{
DISCLAIMER
}

This report was prepared as an account of work sponsored by an agency of the United States Government. Neither the United States Government nor any agency thereof, nor Battelle Memorial Institute, nor any of their employees, makes any warranty, express or implied, or assumes any legal liability or responsibility for the accuracy, completeness, or usefulness of any information, apparatus, product, or process disclosed, or represents that its use would not infringe privately owned rights. Reference herein to any specific commercial product, process, or service by trade name, trademark, manufacturer, or otherwise does not necessarily constitute or imply its endorsement, recommendation, or favoring by the United States Government or any agency thereof, or Battelle Memorial Institute. The views and opinions of authors expressed herein do not necessarily state or reflect those of the United States Government or any agency thereof.

\author{
PACIFIC NORTHWEST NATIONAL LABORATORY \\ operated by \\ BATTELLE \\ for the \\ UNITED STATES DEPARTMENT OF ENERGY \\ under Contract DE-AC05-76RL01830
}

Printed in the United States of America

Available to DOE and DOE contractors from the

Office of Scientific and Technical Information,

P.O. Box 62, Oak Ridge, TN 37831-0062;

ph: (865) 576-8401

fax: $(865) 576-5728$

email: reports@adonis.osti.gov

\footnotetext{
Available to the public from the National Technical Information Service, U.S. Department of Commerce, 5285 Port Royal Rd., Springfield, VA 22161 ph: (800) 553-6847 fax: $(703) 605-6900$

email: orders@ntis.fedworld.gov

online ordering: http://www.ntis.gov/ordering.htm
}

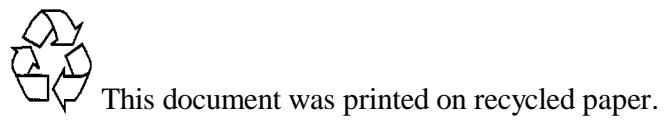




\section{Trends in U.S. Venture Capital Investments Related to Energy: 1980 through the Third Quarter of 2010}

JJ Dooley

November 2010

Prepared for the U.S. Department of Energy under Contract DE-AC05-76RL01830

Pacific Northwest National Laboratory

Richland, Washington 99352 


\begin{abstract}
This report documents trends in U.S. venture capital investments over the period 1980 through the third quarter of calendar year 2010 (2010 Q1+Q2+Q3). Particular attention is given to U.S. venture capital investments in the energy/industrial sector over the period 1980-2010 Q1+Q2+Q3 as well as in the more recently created cross-cutting category of CleanTech over the period 1995-2010 Q1+Q2+Q3. During the early 1980s, U.S. venture capital investments in the energy/industrial sector accounted for more than $20 \%$ of all venture capital investments. However subsequent periods of low energy prices, the deregulation of large aspects of the energy industry, and the emergence of fast growing new industries like computers (both hardware and software), biotechnology and the Internet quickly reduced the priority accorded to energy/industrial investments. To wit, venture capital investments related to the energy/industrial sector accounted for only 1\% of the $\$ 132$ billion (in real 2010 US\$) invested in 2000 by the U.S. venture capital community. The significant increase in the real price of oil that began in 2003-2004 correlates with renewed interest and increased investment by the venture capital community in energy/industrial investment opportunities. Venture capital investments for 2009 for the energy/industrial sector accounted for $\$ 2.4$ billion or slightly more than $13 \%$ of all venture capital invested that year. The total venture capital invested in energy/industrial during the first three quarters of 2010 is close to \$2.4 billion accounting for slightly less than $15 \%$ of all venture capital investments during the first three quarters of 2010. In 2009, the aggregate amount invested in CleanTech was \$2.1 billion (11\% of the total US venture capital invested in that lean year) and for the first three quarters of 2010 US venture capital investments in CleanTech have already exceeded $\$ 2.8$ billion (18\% of all US venture capital investments made during the first three quarters of 2010). Between 2004 and 2009, U.S. venture capital investments in energy/industrial as well as CleanTech have more than quadrupled in real terms.
\end{abstract}

KEY WORDS: venture capital; energy; energy technology; cleantech; United States. 


\section{Contents}

Venture Capital Investments Do Not Equal Private Sector R\&D Expenditures 1

U.S. Venture Capital Investments: 1980-2010 Q1+Q2+Q3 1

U.S. Energy Venture Capital Investments: 1980-2010 Q1+Q2+Q3 4

CleanTech Venture Capital Investments: 1995-2010 Q1+Q2+Q3

Conclusions 9

References 10

\section{List of Figures}

Figure 1 Total U.S. Venture Capital Investments in All Fields: 1980-2010 Q1+Q2+Q3 (millions of real 2010 US\$ Overlain by Major US Recessions during the Same Time Period (NBER, 2010)

Figure 2 U.S. Venture Capital Investments in “Internet-specific” Firms: 1980-2010 Q1+Q2+Q3 (millions of real 2010 US\$

Figure 3 U.S. Venture Capital Investments in Biotechnology: 1980-2010 Q1+Q2+Q3 (millions of real 2010 US\$

Figure 4 U.S. Venture Capital Investments in Energy/Industrial Sectors: 1980-2010 Q1+Q2+Q3 (millions of real 2010 US\$)

Figure 5 Real Price of U.S. Crude Oil (2010 U.S.\$ per BBL) and Selected Major Disruptions to World Oil Markets (MBBL/D)

Figure 6 Average U.S. Venture Capital Investment per deal within the Energy/Industrial Sector 1980-2010 Q1+Q2+Q3 (millions of real 2010 US\$).

Figure 7 U.S. Venture Capital Investments in CleanTech: 1995-2010 Q1+Q2+Q3 (millions of real 2010 US\$). 


\section{Venture Capital Investments Do Not Equal Private Sector R\&D Expenditures}

It is important to note that while "venture capital" investments are often seen to be exclusively about the development of advanced technologies, this is not necessarily true. The National Venture Capital Association (NVCA) makes it clear that "Venture capital focuses on investing in private, young, fast growing companies" (NVCA, 2010). It is therefore more appropriate to read the data presented in this report as first and foremost a measure of what sectors and companies in the US economy venture capital funds believe have the best prospects for rapid growth and less so as a robust input measure of future technological development.

\section{U.S. Venture Capital Investments: 1980-2010 Q1+Q2+Q3}

Figure 1 shows total U.S. venture capital ${ }^{1}$ investments over the period 1980 through the third quarter of 2010. ${ }^{2}$ While US venture capital investments have grown in real terms over this 30 year period from $\$ 1.6$ billion in 1980 to $\$ 16.2$ billion dollars in 2009 (in real 2010 US $\$)^{3}$, there is significant year-to-year variability in the total investment made by the US venture capital community which is likely a reflection of expectations with respect to the health of the US economy as a whole as reflected by the red bars in Figure 1 which indicate major US recessions.

\footnotetext{
1 “U.S. venture capital investments are "defined here as investments made by U.S. controlled venture capital funds in U.S. based companies.” The data here are believed to cover all stages of venture capital financing, e.g., Seed Stage, Later Stage, and Expansion Stage (NVCA, 2010).

2 The principal data set used in this analysis represents the author's attempt to create a coherent and consistent temporal data set U.S. venture capital investments from 1980 to the present. Data describing these investments before 1980 are not publically available. The key data sources used to build this data set are: data on venture capital investments for the period 1980-1989 are from NSB (2002); data on venture capital investments for the period 1990-2004 are taken from NSB (2008); Data on venture capital investments for the period 2005 through the third quarter of 2010 are taken from PricewaterhouseCoopers/National Venture Capital Association (PWC/NVCA, 2010c, d).

${ }^{3}$ All financial data in this report are reported in inflation-adjusted, real 2010 U.S. dollars unless otherwise noted. The conversion of current, nominal, as-spent dollars (which is how most of these data are reported in the original source materials) to inflation-adjusted 2010 U.S. dollars was computed by using Implicit Gross Domestic Product Price Deflators taken from (BEA, 2010). For 2010, an assumption was made that there would be virtually no inflation and therefore the published value for 2009 was used for 2010 as well.
} 


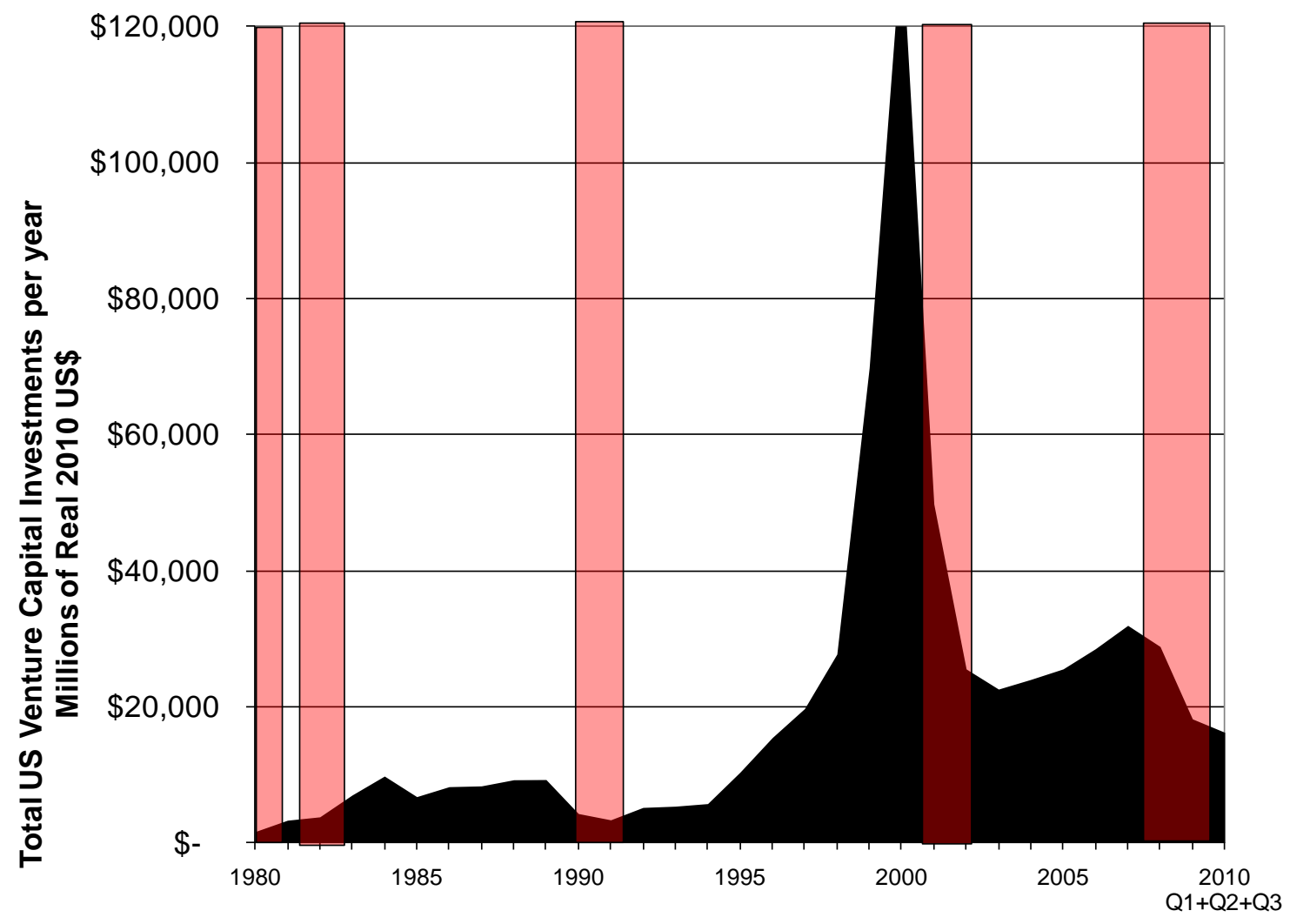

Figure 1 Total U.S. Venture Capital Investments in All Fields: 1980-2010 Q1+Q2+Q3 (millions of real 2010 US\$ Overlain by Major US Recessions during the Same Time Period (NBER, 2010)

The large spike in venture capital activity in the late 1990s to the early 2000s is the most striking feature of Figure 1. In 2000, U.S. venture capital investments reached a record level of $\$ 132$ billion with $\$ 59$ billion ( $45 \%$ of the total) of the funding in this peak devoted to "internet specific" 4 investments. Figure 2 shows how rapidly these "internet specific" U.S. venture capital investments rose and how quickly they declined in the run up to and subsequent aftermath of the bursting of the "dot com bubble."

\footnotetext{
${ }^{4}$ The venture capital category Internet-specific is defined as "a discrete classification assigned to a company whose business model is fundamentally dependent on the Internet, regardless of the company's primary industry category (PWC, 2010).”
} 


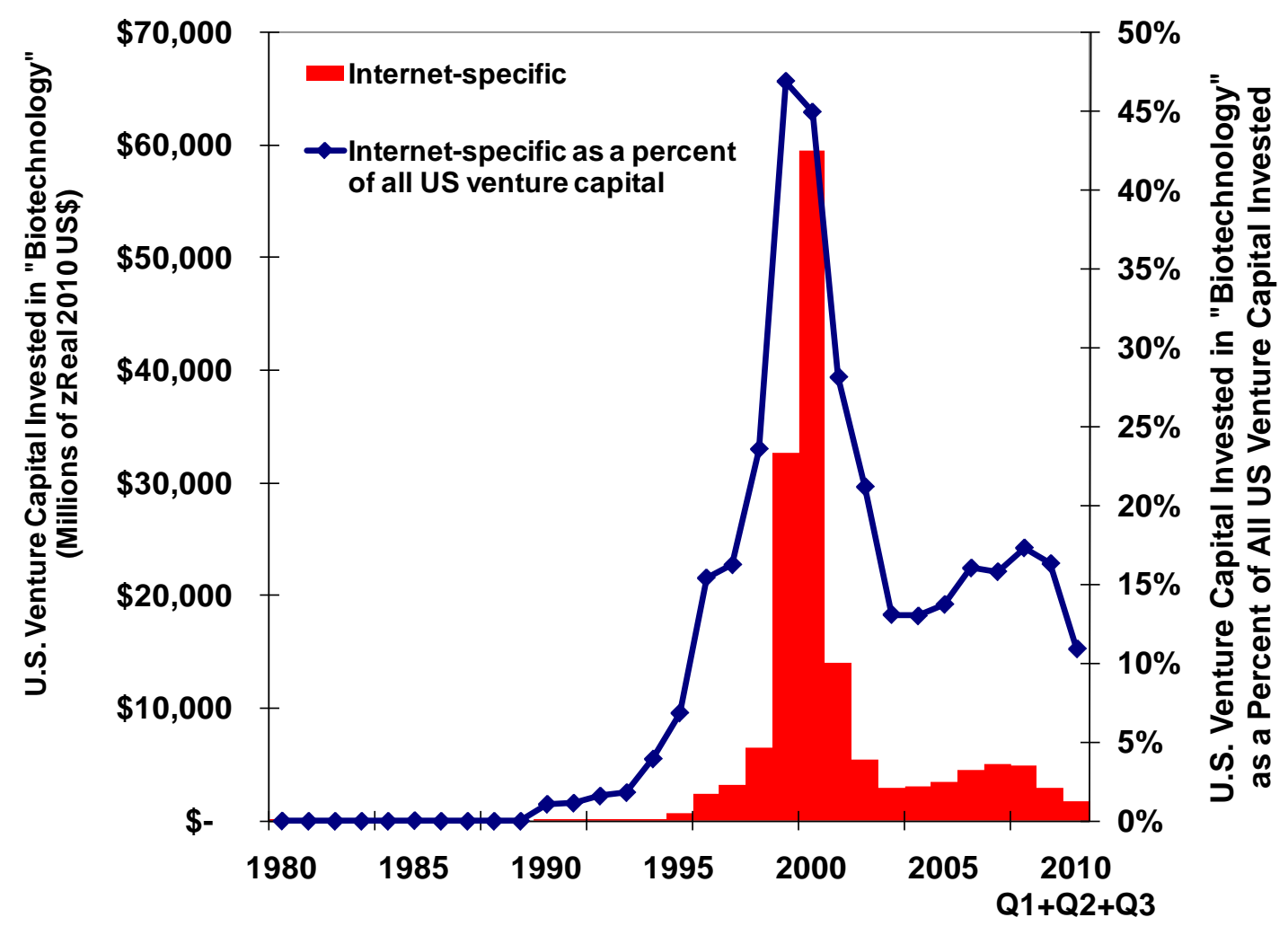

Figure 2 U.S. Venture Capital Investments in “Internet-specific” Firms: 1980-2010 Q1+Q2+Q3 (millions of real 2010 US\$

Figure 3 shows venture capital investments in the biotechnology sector, another prominent recipient of US venture capital funding. ${ }^{5}$ In real inflation-adjusted terms, venture capital investments in biotechnology have been on a mostly uninterrupted growth trajectory since 1980 . Since 2005, biotechnology has consistently commanded more than $15 \%$ of all US venture capital investments.

\footnotetext{
${ }^{5}$ Venture capital investments in "biotechnology" encompasses "Developers of technology promoting drug development, disease treatment, and a deeper understanding of living organisms. Includes human, animal, and industrial biotechnology products and services. Also included are biosensors, biotechnology equipment, and pharmaceuticals” (PWC, 2010).
} 


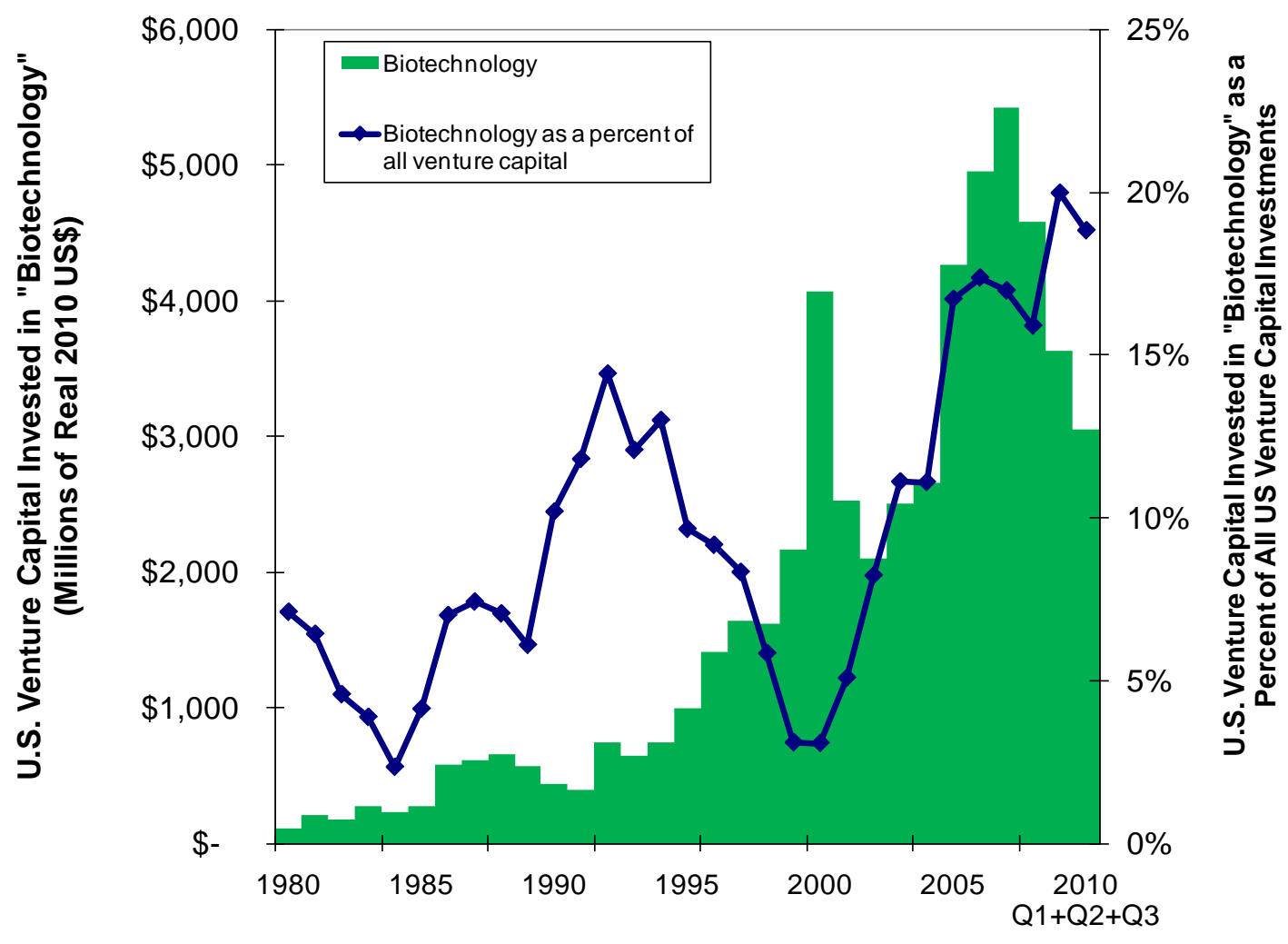

Figure 3 U.S. Venture Capital Investments in Biotechnology: 1980-2010 Q1+Q2+Q3 (millions of real 2010 US\$

\section{U.S. Energy Venture Capital Investments: 1980-2010 Q1+Q2+Q3}

Figure 4 reports U.S. venture capital investments in the energy/industrial sector ${ }^{6}$ over the period 1980-1980-2010 Q1+Q2+Q3. The data in Figure 4 is best interpreted by breaking down this 30 year period into three different eras:

- During the early 1980s, U.S. venture capital investments in the energy/industrial area accounted for more than $20 \%$ of all venture capital investments. As can be seen from Figure 5, this was during a period of high energy prices brought about by two significant global oil crises as well as repeated high level pronouncements from the U.S. government on the need to reduce U.S. dependence on imported energy and more importantly significant commitments of public and private sector funding for the development of new energy technologies. ${ }^{7}$

\footnotetext{
${ }^{6}$ U.S. venture capital investments in the "energy/industrial" sector are targeted at "Producers and suppliers of energy, chemicals, and materials, industrial automation companies and oil and gas exploration companies. Also included are environmental, agricultural, transportation, manufacturing, construction and utility-related products and services (PWC, 2010).

${ }^{7}$ For a detailed discussion of the federal government's response to these energy crises and in particular how this spurred large federal energy R\&D programs, readers are encouraged to consult Dooley (2008).
} 
- However the period from the mid 1980s to the early 2000s was an era characterized by low energy prices, a determined effort by the Regan Administration as well as subsequent Administrations to deregulate many aspects of the energy industry, ${ }^{8}$ along with significant reductions in public and private sector support for energy R\&D -- and in particular the termination of a number of marquee "energy independence" technology development programs that were initiated in the 1970s during the height of the oil crises. Compounding these fundamental changes within the energy sector, this period also saw the emergence of fast growing new industries like computers (both hardware and software), biotechnology and the Internet which were clearly seen as more attractive investments by the US venture capital sector. By the early 1990s, energy/industrial investments were attracting less than $3 \%$ of all U.S. venture capital and by 2000 these investments accounted for only $1 \%$ of the $\$ 132$ billion dollars invested that year by the U.S. venture capital community.

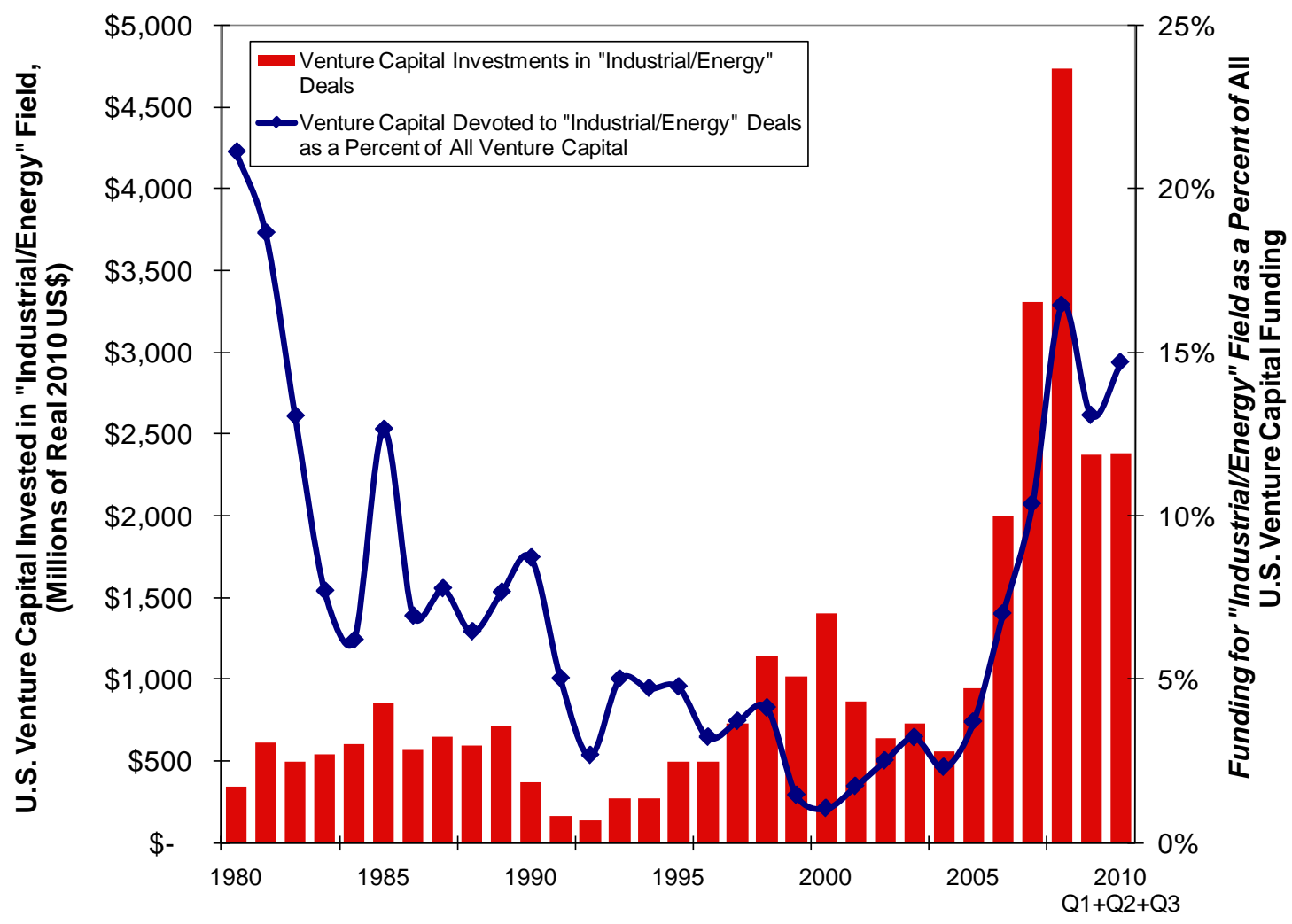

Figure 4 U.S. Venture Capital Investments in Energy/Industrial Sectors: 1980-2010 Q1+Q2+Q3 (millions of real 2010 US\$)

- The significant increase in the real price of oil that began in 2003-2004 correlates with renewed interest and increased investment by the venture capital community in energy/industrial investment opportunities. Venture capital investments in 2009 for the energy/industrial sector accounted for $\$ 2.4$ billion or slightly more than $13 \%$ of all venture

\footnotetext{
${ }^{8}$ For a more detailed discussion of how efforts to deregulate the energy industry led to significant reductions in public and private sector energy R\&D in the US as well as in many other advanced industrialized countries during this period, readers are encouraged to consult Dooley $(1998,2010)$.
} 
capital invested that year. The total venture capital invested in energy/industrial during the first three quarters of 2010 is close to $\$ 2.4$ billion accounting for $15 \%$ of all venture capital investments during the first three quarters of 2010.

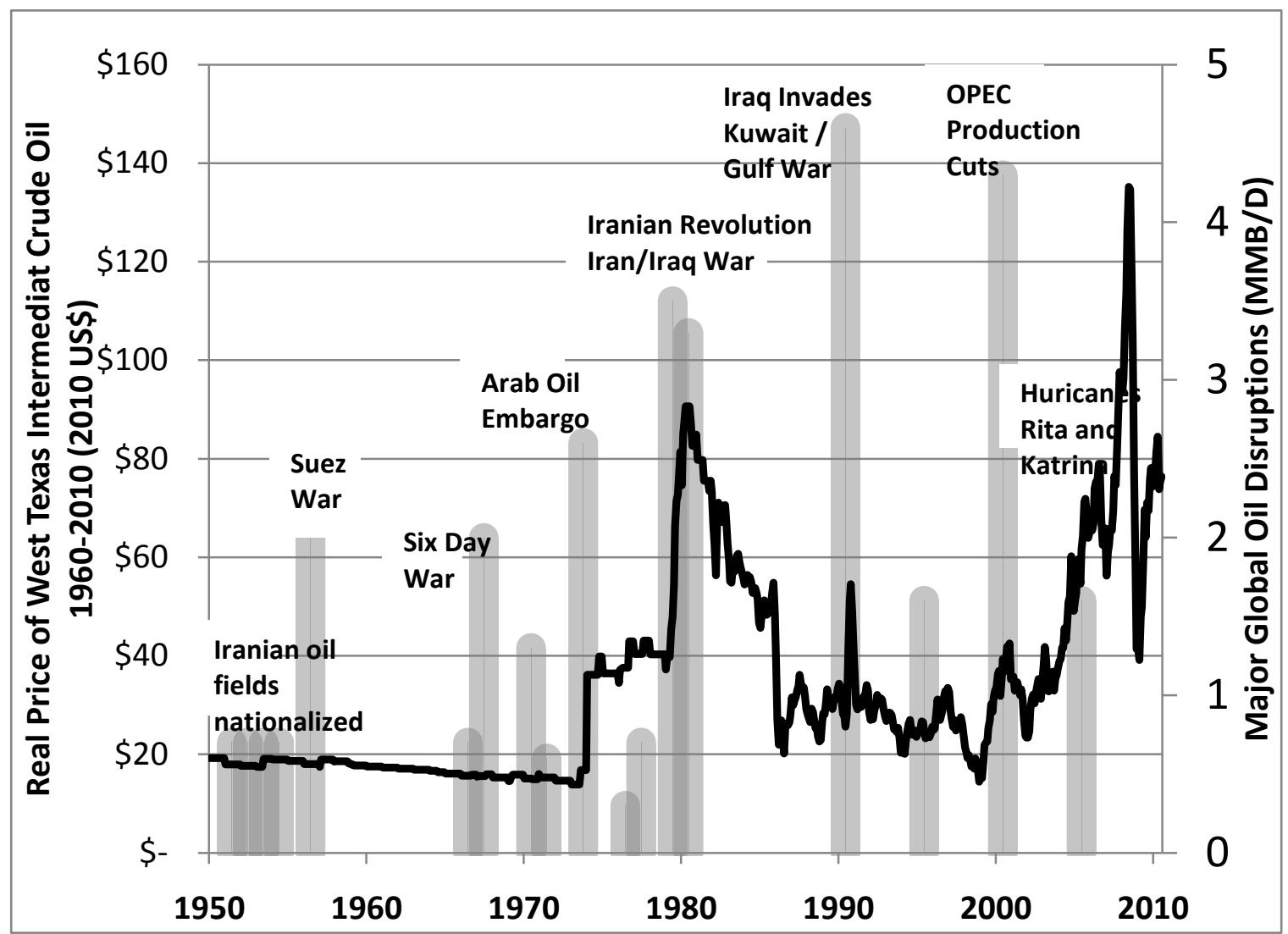

Figure 5 Real Price of U.S. Crude Oil (2010 U.S.\$ per BBL) and Selected Major Disruptions to World Oil Markets (MBBL/D) ${ }^{9}$

While it is clear that the US venture capital community is committing substantially more resources to the energy/industrial sector when compared to funding levels of the early 2000s, Figure 6 shows that for the entire period since 1980 the average venture capital investment made per deal in the energy/industrial sector has never exceeded \$17 million. Given the capital intensive nature of many energy technologies and energy systems, the fact that the average invested per deal in the energy/industrial sector has not exceeded \$17 million over a 30 year period is likely noteworthy.

\footnotetext{
${ }^{9}$ References for Figure 1. Data on the price of West Texas Intermediate Crude Oil from 1950 to the present are from the Federal Reserve (FRED, 2010) while data on global oil disruptions is taken from (EIA, 2005).
} 


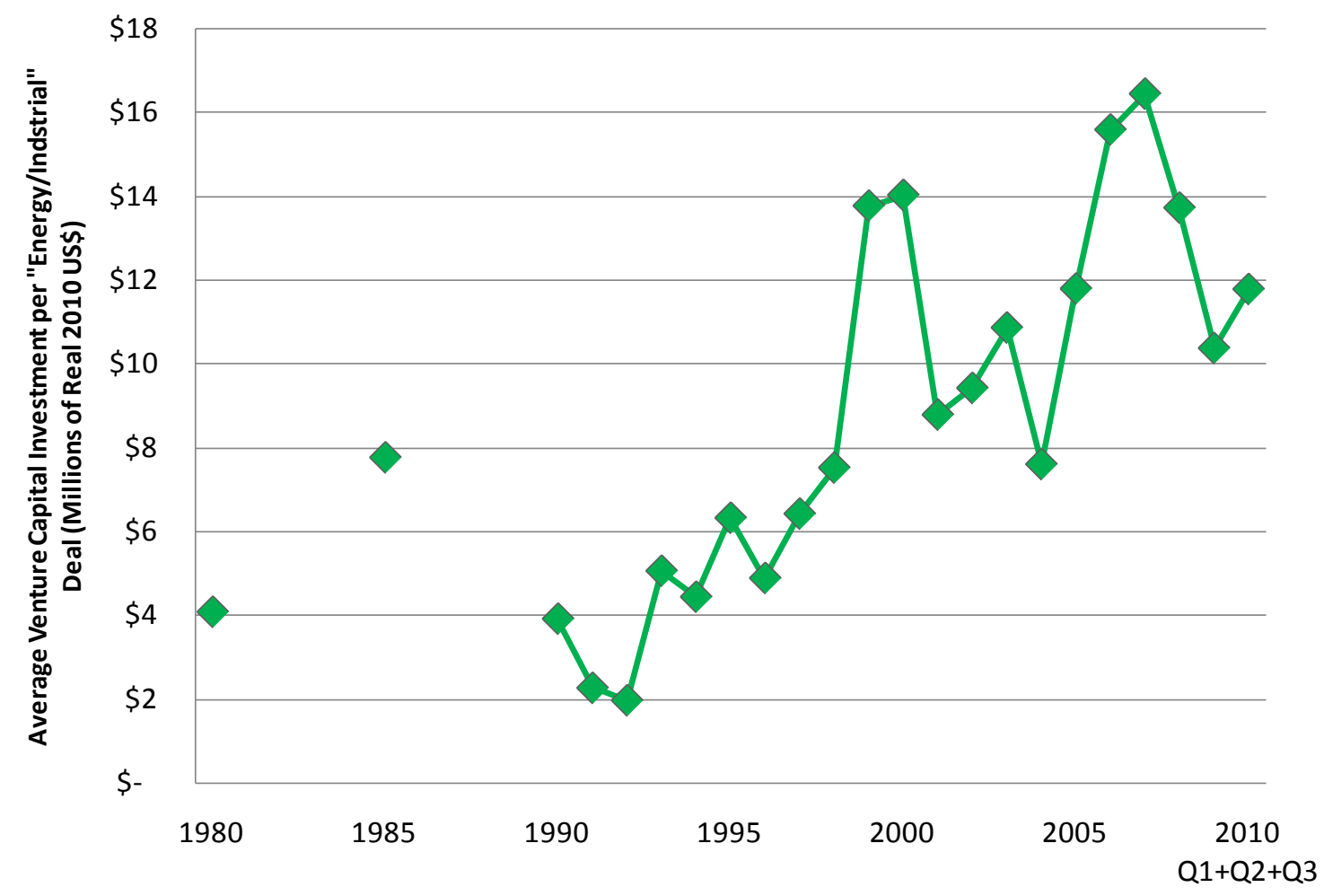

Figure 6 Average U.S. Venture Capital Investment per deal within the Energy/Industrial Sector 1980-2010 Q1+Q2+Q3 (millions of real 2010 US\$)

On the other hand, it is also worth stressing that the data in Figure 6 are literally representing the mathematical average invested per energy/industrial deals during each of these years and there is significant variability in the amount invested for specific deals. This variability in the size and nature of investments by the venture capital community can be seen by looking at investment patters within the ten largest venture capital investments during each of the first three quarters of 2010:,

- Only one of the top ten venture capital investments in the third quarter of 2010 was for an investment in the energy/industrial area. That was a $\$ 70$ million investment in a biofuel firm (PWC/NVCA, 2010b).

- Five out of the top ten venture capital investments during the second quarter of 2010 were for companies in the energy/industrial sector and the amount invested in these five companies ranged from $\$ 350$ - \$50 million. These five venture capital investmetns in the energy/industrial sector during this quarter were: \$350 million for a firm that is developing the infrastructure for "transportation systems that support electric vehicles", \$150 million for a company that develops utility-scale solar power plants, \$70 million for a manufacturer of nanostructure-based photovoltaic technologies, \$60 million for a firm that makes and distrubutes electric cars and trucks, \$55 million for a provider of residential solar electricity, and \$50 million for a developer of "advanced plasma fusion technologies” (PWC/NVCA, 2010e) 
- $\quad$ Three of the top ten venture capital investments in the first quarter of 2010 were for investments in the energy/industrial area. These three investments were: \$115 million for a manufacturer of electric vehicles, $\$ 64$ million for a photovoltaic power system manufacturer, and $\$ 40$ million for a firm that develops "power electronics for solar systems” (PWC/NVCA, 2010a)

\section{CleanTech Venture Capital Investments: 1995-2010 Q1+Q2+Q3}

Figure 7 presents data on US venture capital investments in the so called CleanTech sector. It is important to note that the CleanTech sector is a crosscutting accounting of US venture capital activity and that many of the investments counted under "energy/industrial” are also counted under CleanTech. Data for CleanTech investments from 1995-2010 Q1+Q2+Q3 are presented in Figure $7 .^{10}$

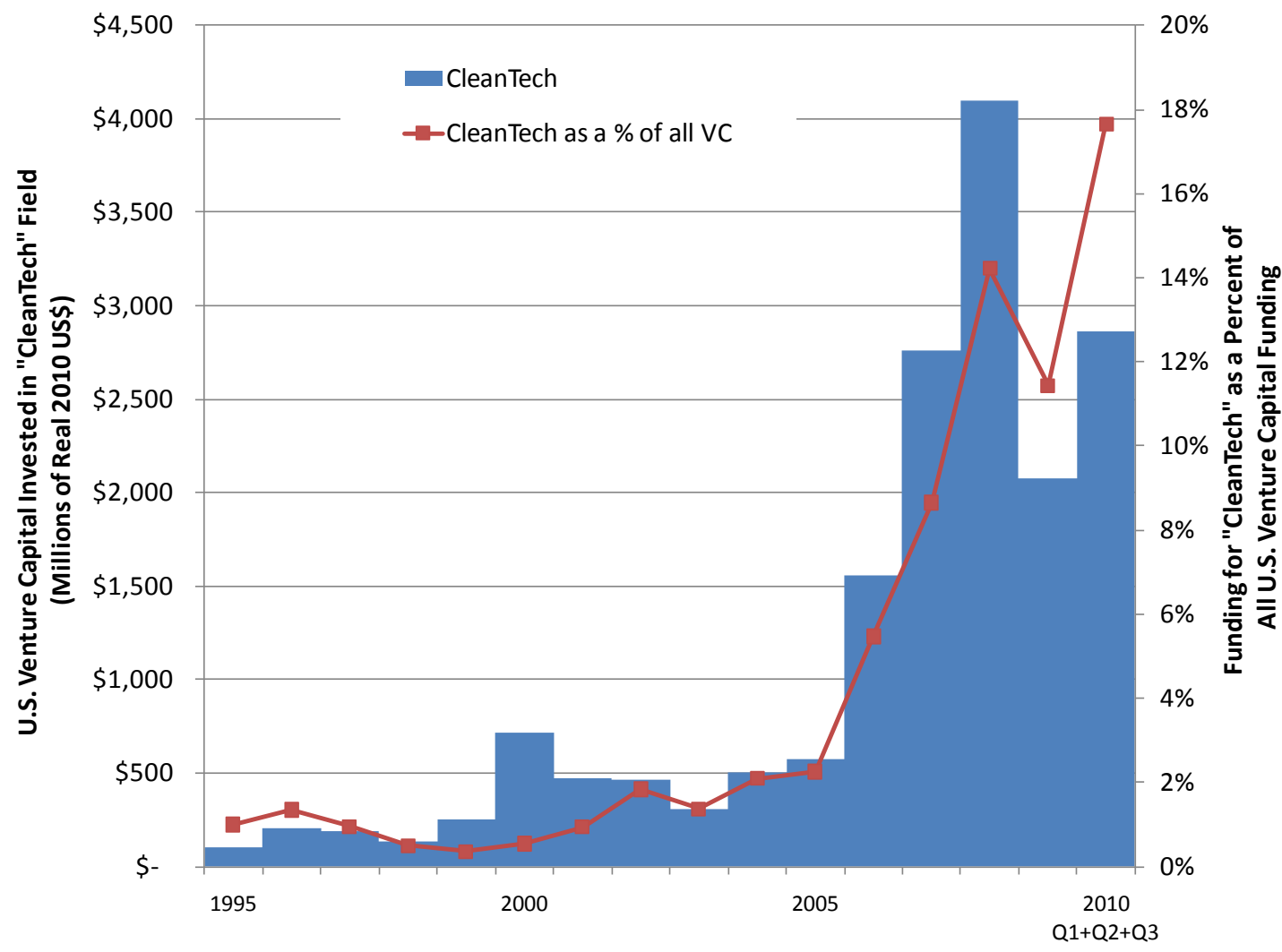

Figure 7 U.S. Venture Capital Investments in CleanTech: 1995-2010 Q1+Q2+Q3 (millions of real 2010 US\$)

\footnotetext{
${ }^{10}$ PWC (2010) describes CleanTech as follows: "The cleantech sector is not one tidy group, but rather an array of distinct sub-sectors: solar, wind, and geothermal energy generation, biofuels, energy storage (power supplies such as batteries and uninterruptible power supplies), nuclear, new pollution-abatement, recycling, clean coal, and water technologies. The common thread is that all of these sub-sectors represent technologies, services, or products aimed at reducing greenhouse gas emissions and other pollutants and promoting energy efficiency and the conservation of natural resources.”
} 
As can be seen from Figure 7, US venture capital investments in the CleanTech sector closely follow the pattern seen in the more specific energy/industrial category discussed above. In 1995, CleanTech venture capital investments were \$104 million dollars and accounted for 1\% of all U.S. venture capital. By 2008, CleanTech accounted for approximately $\$ 4.1$ billion which was approximately $14 \%$ of all venture capital investments that year. In 2009, the aggregate amount invested in CleanTech declined to $\$ 2.1$ billion which accounted for fully $11 \%$ of the total US venture capital invested in that lean year. For the first three quarters of 2010, US venture capital investments in CleanTech have already exceeded $\$ 2.9$ billion and account for $18 \%$ of all US venture capital investments made during the three quarters of 2010. As was the case for investments in energy/industrial sector, the average US venture capital investment per CleanTech deal over the period 1980-2010 Q1+Q2+Q3 has not exceeded \$16 million.

\section{Conclusions}

The U.S. venture capital community and the financial resources it controls have grown significantly since 1980. The focus of U.S. venture capital investments has shifted significantly over this nearly 30 year period as this class of investors has sought out dynamic, fast growing, high potential return on investment opportunities. Computer hardware, computer software, medical devices, biotechnology companies and internet-specific companies have all for relatively brief periods of time been the single largest recipient of U.S. venture capital investments. The energy/industrial sector can only claim to have been the largest recipient of U.S. venture capital funds in the early 1980s, that is in the immediate aftermath of the energy crises of the 1970s and early 1980s. Recent significant increases in the price of oil correlate well with increased venture capital support for energy/industrial firms as well as in the so called "CleanTech" sector. Between 2004 and 2009, U.S. venture capital investments in energy/industrial as well as CleanTech have more than quadrupled in real terms. 


\section{References}

BEA, 2010.Table 1.1.9. Implicit Price Deflators for Gross Domestic Product Bureau of Economic Analysis, US Department of Commerce. 9/9/2010.http://www.bea.gov/national/Index.htm.

Dooley, J, 1998. Unintended consequences: energy R\&D in a deregulated energy market. Energy Policy 26, 547-555.

Dooley, J, 2008. U.S. Federal Investments in Energy R\&D: 1961-2008. Joint Global Change Research Institute, Pacific Northwest National Laboratory, College Park, MD.

Dooley, J, 2010. The Rise and Decline of U.S. Private Sector Investments in Energy R\&D since the Arab Oil Embargo of 1973. Joint Global Change Research Institute, Pacific Northwest National Laboratory, College Park, MD, p. 14.

EIA, 2005.Global Oil Supply Disruptions Since 1951. Energy Information Agency, US Department of Energy. http://www.eia.doe.gov/emeu/security/distable.html.

FRED, 2010.OILPRICE, Spot Oil Price: West Texas Intermediate. Historical data 1946-2010. Federal Reserve Economic Data, Federal Reserve Bank of St. Louis. 2010-08-02.

NSB, 2002. Science and Engineering Indicators - 2002. National Science Board, National Science Foundation, Arlington, VA.

NSB, 2008. Science and Engineering Indicators - 2008. National Science Board, National Science Foundation, Arlington, VA.

NVCA, 2010. Frequently Asked Questions. National Venture Capital Association.

PWC, 2010. MoneyTree ${ }^{\mathrm{TM}}$ Report Definitions and Methodology. PricewaterhouseCoopers.

PWC/NVCA, 2010a. Q1 2010 - Largest U.S. Venture Capital Investments. PricewaterhouseCoopers/National Venture Capital Association, Washington, DC.

PWC/NVCA, 2010b. Q3 2010 - Largest U.S. Venture Capital Investments. PricewaterhouseCoopers/National Venture Capital Association, Washington, DC.

PWC/NVCA, 2010c. Total U.S. Investments by Year Q1 1995 - Q3 2010.

PricewaterhouseCoopers/National Venture Capital Association, Washington, DC.

PWC/NVCA, 2010d. VC Investments Q2 '10 - MoneyTree - National Data.

PricewaterhouseCoopers/National Venture Capital Association, Washington, DC.

PWC/NVCA, 2010e. Venture Capital Investments Q2-2010 - MoneyTree Results: Top Deals. PricewaterhouseCoopers/National Venture Capital Association, Washington, DC. 